\title{
Bioeffects of Transient and Low-Intensity Ultrasound on Nanoparticles for a Safe and Efficient DNA Delivery
}

\section{Mei Fen Shih ${ }^{1}$, Chung Huang $\mathrm{Wu}^{2}$ and Jong Yuh Cherng ${ }^{3 *}$}

${ }^{1}$ Department of pharmacy, Chia-Nan University of Pharmacy and Science, 60 Erh-Jen Rd., Sec 1, Jen-Te, Taiwan

${ }^{2}$ Medical Equipment Maintenance Office, Songshan Armed Forces General Hospital, Taipei, Taiwan

${ }^{3}$ Department of Chemistry and Biochemistry, National Chung Cheng University, 168 University Rd., Chia-Yi, Taiwan

\begin{abstract}
An important advantage of polymer-based gene delivery systems over viral transfection systems is that transient gene expression without the safety concerns can be achieved. In addition to the polymeric systems to deliver DNA, therapeutic ultrasound is potentially useful because ultrasound energy can be transmitted through the body without damaging tissues and could be applied on a restricted area where the desired DNA is to be expressed. In this study, bioeffects of ultrasound on the transfection efficiency and cytotoxicity of DNA-polymer complexes on mammalian cells (HEK-293 and COS-7 cell lines) were investigated.

Polymer-DNA ratios for optimal transfection efficiency and the size of PEI/DNA or PDMAEMA/DNA complexes were found not affected by ultrasound treatment. Also, electrophoresis results indicate that the tertiary DNA structure was not influenced by ultrasound when exposed up to 10 seconds. More importantly, cationic polymer-mediated cell transfection was significantly enhanced and reached a $150 \%$ increase by using ultrasound. Cytotoxicity of HEK-293 and COS-7 cell lines was not observed after ultrasound. Therefore, these results indicate that clinical applications of ultrasound could be used as a safe and efficient method for non-viral gene delivery.
\end{abstract}

Keywords: Transfection; Polymer-DNA complexes; Ultrasound; Cytotoxicity

\section{Introduction}

Ultrasound has evolved from being primarily used for diagnosis into treatment of diseases (e.g. cancer) by delivery of drugs, proteins (interleukins, antibodies) or nucleic acids (DNA, siRNA) to the site of diseases [1-6]. Rapid and efficient transfer of therapeutic agents is a critical first step in therapy and mild or no cytotoxicity is a favorable step after treatment. In gene transfection, non-viral/physical in-vitro techniques are commonly used to mediate gene transfer and transgene expression with a varying degree of efficiency including liposome/
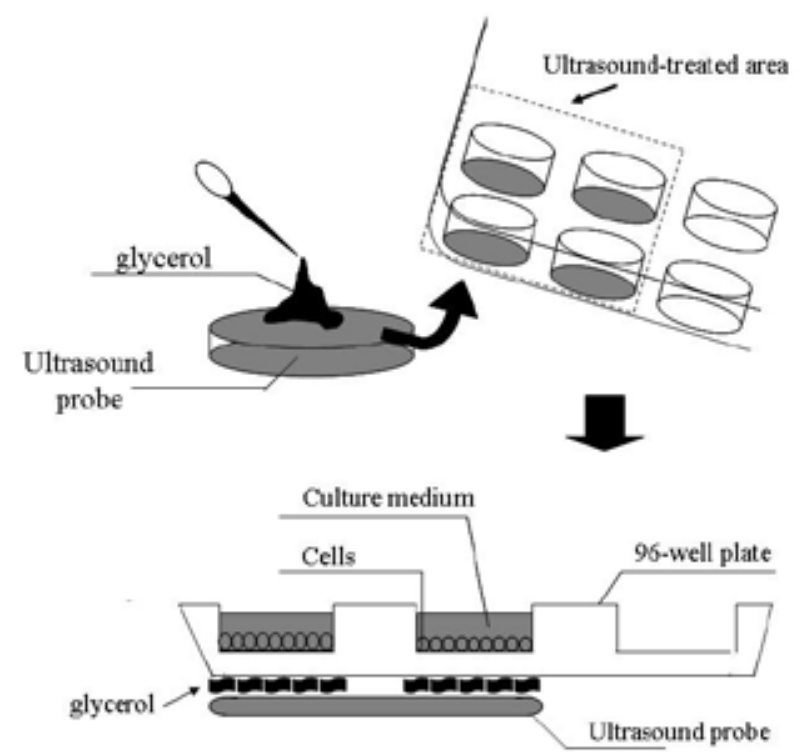

The position setting of ultrasound-mediated transfection for gene transfer in cells polymer-mediated gene transfer [7,8]. The use of ultrasound in a combination with these techniques improves transfection efficiency and site specificity [9]. Ultrasound can also increase the permeability of cell membrane to macromolecules such as plasmid DNA. Enhancement of gene expression was then observed by irradiating ultrasonic wave to the tissue after injection of DNA [10]. However, reduced cell viability in vitro and in vivo was reported because of possible acoustic pressure or ultrasound-caused cavitation [11]. Low-intensity pulsed ultrasound, transmitting as an acoustic pressure wave and applying mechanical stress indirectly to the tissues, has been reported to promote osteogenesis and protein synthesis, calcium uptake, and DNA synthesis in different cells and this ultrasound application is flexible and safe for use in gene delivery applications [12].

It was reported that a combination of microbubbles with ultrasound could further increase the gene expression level in tumor tissues or tendons $[13,14]$. This is because the microbubbles (could be a few $\mu \mathrm{m}$ in size) with a thin shell such as albumin are more stable compared to air bubbles (conventional sonoporation) [15]. Although microbubbles demonstrated an ultrasound-targeted capability [16], a high power pulse is required to destroy the microbubbles so concerns over cytotoxicity or irreversible damage remain $[15,17]$.

In this study, we use a transient and low-intensity ultrasound to enhance the delivery of complexes of DNA with two polymers (PEI and PDMAEMA). The exposure time of ultrasound is 10 seconds with

${ }^{*}$ Corresponding author: Jong Yuh Cherng, Department of Chemistry and Biochemistry, National Chung Cheng University, 168 University Rd., Chia-Yi, Taiwan, E-mail: jycherng@yahoo.com

Received July 14, 2011; Accepted August 23, 2011; Published August 25, 2011

Citation: Shih MF, Wu CH, Cherng JY (2012) Bioeffects of Transient and LowIntensity Ultrasound on Nanoparticles for a Safe and Efficient DNA Delivery. J Nanomedic Nanotechnol 6:276. doi:10.4172/2157-7439.1000276

Copyright: ( 2012 Shih MF, et al. This is an open-access article distributed under the terms of the Creative Commons Attribution License, which permits unrestricted use, distribution, and reproduction in any medium, provided the original author and source are credited. 
9 cycles (separated by an interval of 230 seconds). We hypothesize that the procedure would minimize cytotoxicity without compromising the increase of transfection efficiency. Also, these polymer-DNA complexes are stable with sizes smaller than $0.2 \mu \mathrm{m}$. Comparing to microbubbles commonly present with a size around 1-8 $\mu \mathrm{m}[15,18]$, their stability and vascular damage are major determinants of in vivo efficacy $[19,20]$.

\section{Experimental}

\section{Chemicals}

Luria broth (LB) and o-Nitrophenyl- $\beta$-D-Galactopyranoside (ONPG) were purchased from Sigma. 3'-[1-(phenylaminocarbonyl)3,4-tetrazolium]-bis (4-methoxy-6-nitro) benzene sulfonic acid hydrate (XTT assay kit) was obtained from Roche. Agarose and restriction enzyme KpnI $(10 \mathrm{U} / \mu \mathrm{l})$ were purchased from Invitrogen. Polyethyleneimine (PEI, $\mathrm{Mw}=25 \mathrm{kDa}$ ) was from Aldrich and Poly(2(dimethylamino)ethyl methacrylate) (PDMAEMA, Mw=130 kDa) was synthesized and purified as described previously [21]. Dulbecco's modified Eagle medium (DMEM) supplemented with 10000U/ml Penicillin and $10 \mathrm{mg} / \mathrm{ml}$ streptomycin for HEK-293 cell line (CCRC 60019) and COS-7 (CCRC 60094) which were obtained from Food Industry Research \& Development Institute (Taiwan).

\section{Plasmid DNA}

Plasmid (pCMV lacZ), which encodes the lacZ gene for $\beta$-galactosidase, was driven by a SV40 promoter to gene expression.


$\mathrm{ml}$ of ampicillin) and purified by column chromatography (QIAGENMega kit). The purity of plasmid DNA was determined by a UV Spectrometer at $260 / 280 \mathrm{~nm}$ with a ratio higher than 1.80 . Agarose $(0.7 \%)$ gel electrophoresis analysis using restriction enzyme (Kpn I) showed that plasmid DNA was mainly in a supercoiled form.

\section{Preparation of polymer-based DNA delivery systems}

Plasmid DNA (with a final concentration of $5 \mu \mathrm{g} / \mathrm{ml}$ ) was prepared in plain DMEM. PEI and PDMAEMA were prepared in plain DMEM and various ratios of polymer/DNA $(0.5 / 1,1 / 1,2 / 1,3 / 1,5 / 1)$ were

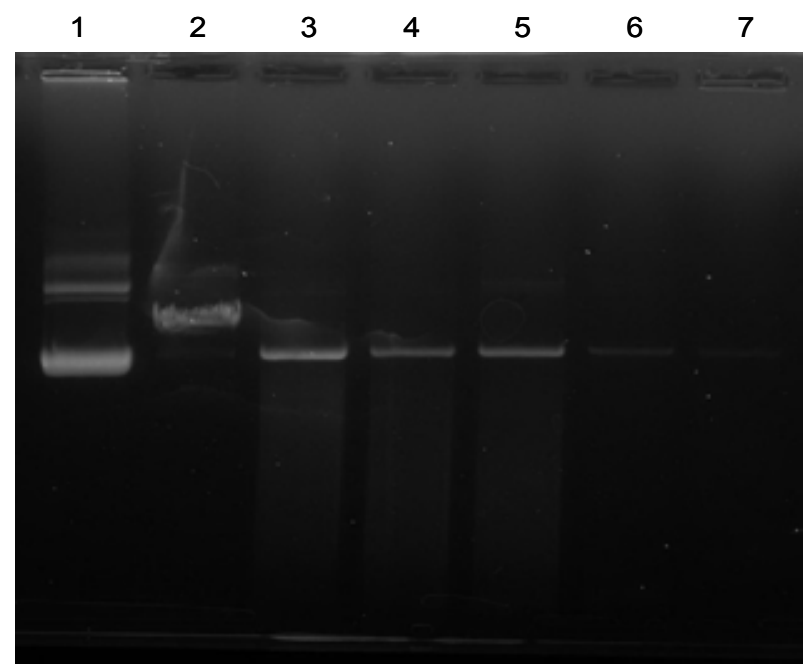

Figure 1: Effects of a high power (140W) ultrasound on DNA tertiary structures. Lane 1: control plasmid DNA, Lane 2: plasmid DNA treated with $K p n l$ restriction enzyme, Lane 3-7: plasmid DNA treated with the ultrasound for $10 \mathrm{sec}, 1 \mathrm{~min}, 3 \mathrm{~min}, 10 \mathrm{~min}$, and $20 \mathrm{~min}$.

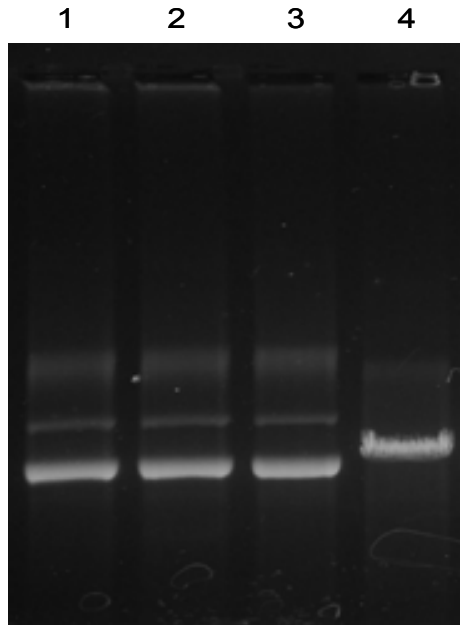

Figure 2: Effects of a low frequency (30W; $3 \mathrm{~W} / \mathrm{cm}^{2}$ from $36 \mathrm{~mm}$ transducer) ultrasound treatment on plasmid DNA tertiary structures. Lane 1: control plasmid DNA, Lane 2-3: plasmid DNA was treated with the ultrasound treatment for $90 \mathrm{sec}$, and $30 \mathrm{~min}$, Lane 4: plasmid DNA was treated with $\mathrm{Kpnl}$ restriction enzyme.

reached by adding the polymer into DNA. DNA/polymer complexes were then formed after 30 minutes prior to transfection.

\section{Ultrasound treatment}

Low-intensity pulsed ultrasound $\left(1.5 \sim 2.2 \mathrm{MHz}, 3 \mathrm{~W} / \mathrm{cm}^{2}\right.$, NeoTec N101, NeoAsia Enterprise, Taiwan) was used. The ultrasound was delivered in a form of square waves and transmitted by a $36 \mathrm{~mm}$ flat-top probe. The 96 -well plates were divided into 24 areas to apply ultrasound treatment. In order to minimize the effect of raising temperature from ultrasound, each area was treated for $10 \mathrm{sec}$ before moving to the next area. Each area was treated with an upward-direction ultrasound for a total of 9 cycles (interval $=230$ seconds/cycle) from bottom of culture plates (see diaphragm 1). The tertiary structure of plasmid DNA was examined after ultrasound treatment. Plasmid DNA was either treated with a ultrasonic cleaner with high power $(40 \mathrm{KHz}, 140 \mathrm{~W}$, WUC$\mathrm{D} 06 \mathrm{H}$, Double eagle enterprise, Taiwan) for $10 \mathrm{sec}, 1 \mathrm{~min}, 3 \mathrm{~min}, 10$ $\mathrm{min}$, and $20 \mathrm{~min}$ or lower power $\left(3 \mathrm{~W} / \mathrm{cm}^{2} ; 30 \mathrm{~W}\right.$ in total from a $36 \mathrm{~mm}$ probe) for $90 \mathrm{sec}$ or $30 \mathrm{~min}$ prior to electrophoresis analysis.

\section{Cell cultures}

HEK-293 and COS-7 cell lines were used to evaluate the effectiveness of ultrasound on transfection efficiency. The HEK-293 cell line was cultured in completed DMEM culture medium (from Sigma), containing 10\% inactivated horse serum (from HyClone),

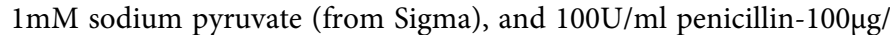
$\mathrm{ml}$ streptomycin (from Invitrogen). The COS-7 cell line was cultured in completed DMEM culture medium, containing 5\% inactivated FBS (from HyClone), $1 \mathrm{mM}$ sodium pyruvate, $25 \mathrm{mM}$ Hepes (from Sigma), and $100 \mathrm{U} / \mathrm{ml}$ penicillin- $100 \mathrm{U} / \mathrm{ml}$ streptomycin-100 $\mu \mathrm{g} /$ $\mathrm{ml}$ amphotericin (from Invitrogen). Both cells were cultured in an incubator (Sanyo MCO-17AIC) at $37^{\circ} \mathrm{C}$ and $5 \% \mathrm{CO}_{2}$.

\section{In vitro transfection}

Cells were seeded into a 96-well plate at a density of $1 \times 10^{4}$ cells/ well and grown overnight (with $70-80 \%$ confluence) at $37^{\circ} \mathrm{C}$ and $5 \%$ $\mathrm{CO}_{2}$. Prior to transfection, cells were rinsed with plain DMEM to avoid FBS interference. $200 \mu \mathrm{l}$ of polymer/DNA complexes was added to each 
well and incubated for 1 hour. Ultrasound treatment was carried out with a low intensity $\left(3 \mathrm{~W} / \mathrm{cm}^{2}, 90 \mathrm{sec}\right.$ in total divided in 9 cycles; that is $10 \mathrm{sec} / \mathrm{cycle}$ with an interval of $230 \mathrm{sec}$ ) and then incubated at $37^{\circ} \mathrm{C}$ and $5 \% \mathrm{CO}_{2}$ for further 30 minutes. After incubation, the polymer/ DNA complex was removed by aspiration and the each well was refilled with $100 \mu$ l of completed DMEM culture medium. After 48 hours, transfection efficiency was determined by $\beta$-galactosidase gene expression. Briefly, cells were washed once with PBS prior to adding $20 \mu \mathrm{l}$ lysis buffer $\left(\mathrm{P}^{\mathrm{H}} 8.0\right.$, contains $0.5 \mathrm{mM}$ tris base, $1.5 \mathrm{mM} \mathrm{NaCl}$ and $1 \%$ triton X) per well and incubating at $4^{\circ} \mathrm{C}$ for $20 \mathrm{~min}$. After that, $180 \mu \mathrm{l}$ of ONPG staining solution $\left(0.09 \mathrm{M}\right.$ sodium phosphate, $\mathrm{P}^{\mathrm{H}} 7.5,0.9 \mathrm{mM}$ $\mathrm{MgCl}_{2}, 0.67 \mathrm{mg} / \mathrm{ml} \mathrm{ONPG}$ ) was added into each well and incubated at $37^{\circ} \mathrm{C}$ and $5 \% \mathrm{CO}_{2}$ for 60 minutes. The absorbance was determined at 405/630nm using an ELISA plate reader (Labsystems Multiskan MS).

\section{Cell viability of transfected cells}

To determine the influence of ultrasound on cell viability, the number of viable cells was measured using an XTT colorimetric assay according to the manufacture protocol from Roche, Taiwan. Briefly, mixing $5 \mathrm{ml}$ of XTT stock solution and $100 \mu$ l of electron-coupling reagent prior to the assay. $50 \mu \mathrm{l}$ of the XTT mixture was added to each well and incubated for $60 \mathrm{~min}$ at $37^{\circ} \mathrm{C}$ and $5 \% \mathrm{CO}_{2}$. The absorbance was determined at $490 / 690 \mathrm{~nm}$ using an ELISA plate reader (Labsystems Multiskan MS).

\section{Statistical analysis}

Data of replicates from each group of six samples were combined from at least three different experiments. A two-tailed student's unpaired test was used to compare the mean values of two populations with respect to a significant difference in transfection efficiency and cytotoxicity (GraphPad Prism 3.0 software).

\section{Results}

\section{Effects of ultrasound on plasmid DNA tertiary structures and sizes of polymer-DNA complexes}

Plasmid DNA was initially in supercoiled topology (Figure 1, lane 1). After $10 \mathrm{sec}$ exposure of a high power (140W) ultrasound, the amount of DNA was reduced (lane 3). The reduced DNA was not converted to a linear form which should be visible as shown in lane 2 but was degraded into small fragments (shown as a smear pattern, lane 3-5). The DNA was degraded more under $140 \mathrm{~W}$ ultrasound as the treatment time was increased (from $1 \mathrm{~min}$, to $20 \mathrm{~min}$; lane 4 and lane 7 , respectively). Conversely, a low power $\left(30 \mathrm{~W} ; 3 \mathrm{~W} / \mathrm{cm}^{2}\right.$ from 36 $\mathrm{mm}$ probe) ultrasound appeared not to affect the integrity of DNA in either $90 \mathrm{sec}$ or $30 \mathrm{~min}$ treatment group (Figure 2; lane 2 and lane 3, respectively). The sizes of PEI-DNA and PDMAEMA-DNA complexes were not affected either by a low power $(30 \mathrm{~W})$ or a high power $(140 \mathrm{~W})$ ultrasound (data not shown).

\section{Bioeffects of ultrasound on COS-7 cells}

PEI/DNA complexes: In transfection efficiency studies with PEI and COS-7 cells, the optimal transfection ratio for PEI-DNA complexes without ultrasound treatment (control) was $1 / 1(\mathrm{w} / \mathrm{w})$ (Figure 3A). As we have shown previously [21], a lower ratio (e.g. PEI-DNA ratio $=0.5 / 1)$ increased the particle size of complexes over $0.3 \mu \mathrm{m}$ and a high ratio (e.g. PEI-DNA ratio $>2 / 1$ ) also increased their cytotoxicity. Both circumstances would result in decreased transfection efficiency.

Exposure to ultrasound (10 sec, 9 cycles with $230 \mathrm{sec}$ interval) increased transfection efficiency (Figure $3 \mathrm{~A}, \mathrm{p}<0.01$ ) for PEI/DNA complexes at $1 / 1$ ratio. For other ratios of PEI/DNA, no significant increase in transfection efficiency was observed before and after the ultrasound exposure. In Figure 3B, there is a slight decrease in cell viability of PEI/DNA complexes on COS-7 cells at higher polymerDNA ratios (from 2/1 to 5/1). This decrease was due to the effect of cationic polymers upon cells which is well documented [22]. Importantly, ultrasound treatment did not cause any cytotoxicity under our test conditions when compared to controls.

PDMAEMA/DNA complexes: The optimal ratio of PDMAEMA/ DNA complexes for transfection was determined to be at $5 / 1(\mathrm{w} / \mathrm{w})$ (Figure 4A). Further higher polymer/DNA ratios would result in significant cytotoxicity. However, for lower ratios (from $0.5 / 1$ to $2 / 1$ ), particle sizes of complexes were observed over $0.3 \mu \mathrm{m}$ and were the cause of lower transfection efficiency [21] compared to the size of complexes at $3 / 1$ or $5 / 1$ was $0.2 \mu \mathrm{m}$ and $0.15 \mu \mathrm{m}$, respectively. After ultrasound treatments, a $150 \%$ increase in transfection efficiency was found in the complexes at ratios of $3 / 1$ and $5 / 1$ with small sizes $(<0.2$ $\mu \mathrm{m})$. In contrast, the transfection efficiency of complexes at $2 / 1$ with a larger size $(0.3 \mu \mathrm{m})$ did not show a beneficial effect on increasing gene transfer. Again, the ultrasound treatment did not induce more cytotoxicity in comparison with controls (without ultrasound) (Figure $3 \mathrm{~B})$.

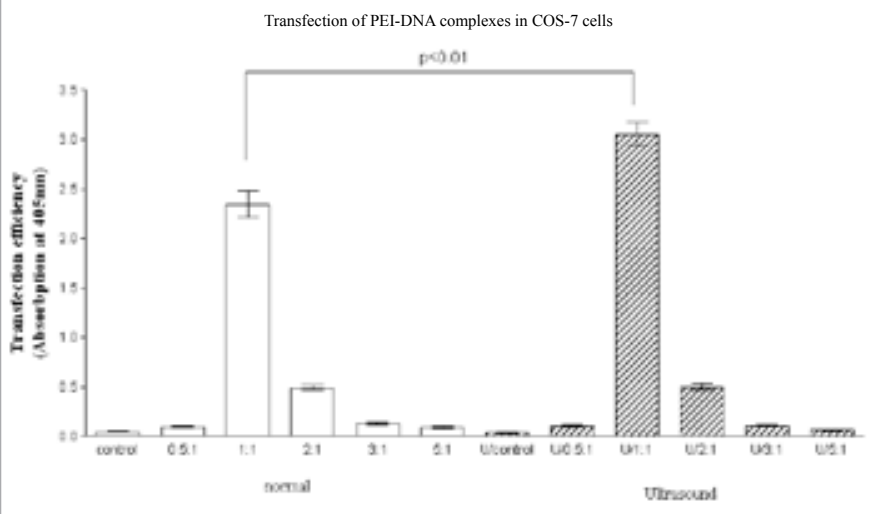

Figure 3A: Effects of the ultrasound treatment on transfection efficiency of PEI-DNA complexes at various ratios. Cells were treated with PEI-DNA complexes and ultrasound or without (normal group) a low energy ultrasound for $10 \mathrm{sec}$ and 9 cycles. Values are expressed as Mean \pm SD in triple experiments. Statistics are shown for cells treated with ultrasound $(p<0.01)$ compared to controls.

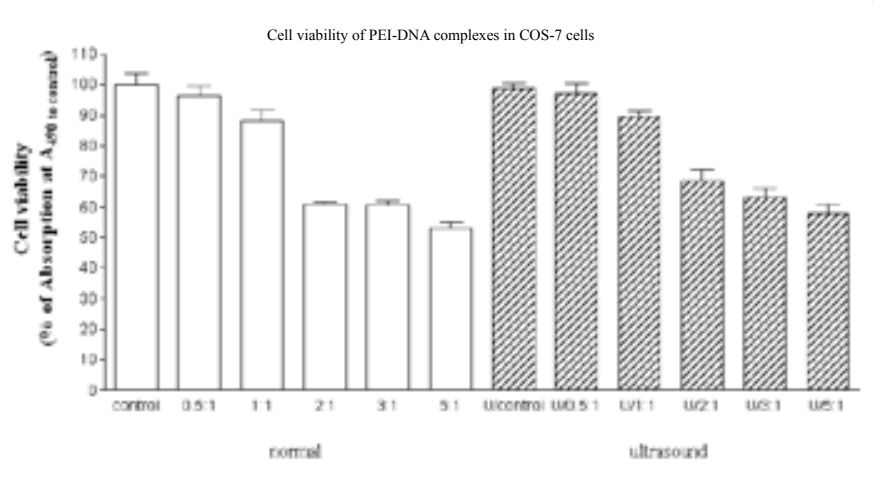

Figure 3B: Effects of the ultrasound treatment on cytotoxicity in PEI-DNA complexes at various ratios. Cells were treated with PEI-DNA complexes and ultrasound or without (normal group) a low energy ultrasound for $10 \mathrm{sec}$ and 9 cycles. Values are expressed as Mean \pm SD in triple experiments. 
Citation: Shih MF, Wu CH, Cherng JY (2012) Bioeffects of Transient and Low-Intensity Ultrasound on Nanoparticles for a Safe and Efficient DNA Delivery. J Nanomedic Nanotechnol 6:276. doi:10.4172/2157-7439.1000276

Page 4 of 6

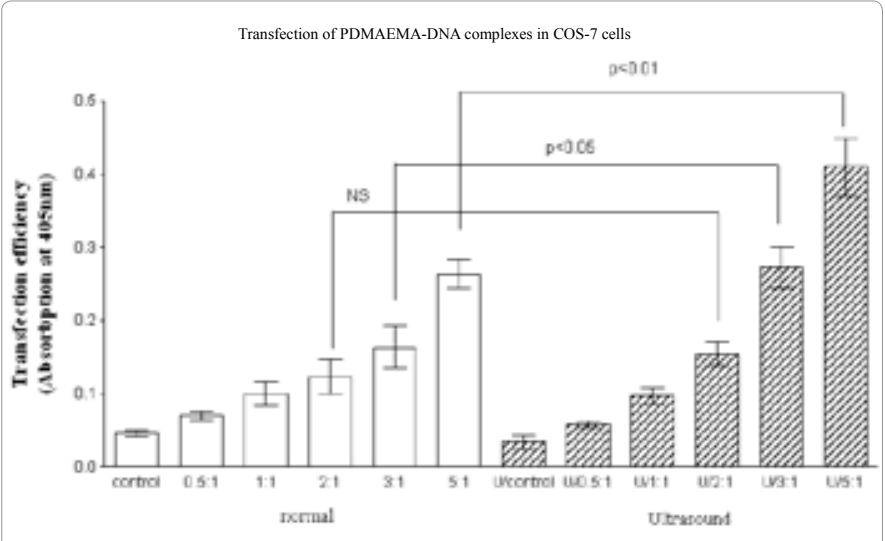

Figure 4A: Effects of the ultrasound treatment on transfection efficiency of PDMAEMA-DNA complexes at various ratios. Cells were treated with PDMAEMA-DNA complexes and ultrasound or without (normal group) a low energy ultrasound for $10 \mathrm{sec}$ and 9 cycles. Values are expressed as Mean \pm $\mathrm{SD}$ in triple experiments. Statistics are shown for cells treated with ultrasound compared to untreated cells at ratios of 5/1 $(p<0.01), 3 / 1(p<0.05)$ and $2 / 1$ (NS not statistically different).

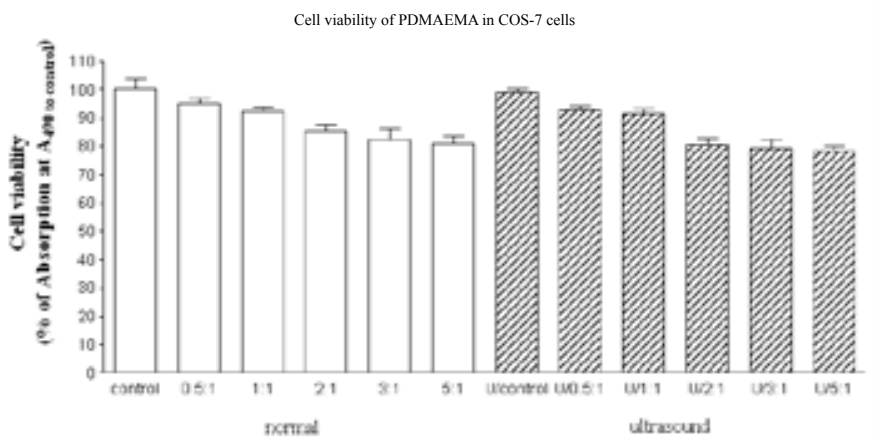

Figure 4B: Effects of the ultrasound treatment on cytotoxicity of PDMAEMA-DNA complexes at various ratios. Cells were treated with PDMAEMA-DNA complexes and ultrasound or without (normal group) a low energy ultrasound for $10 \mathrm{sec}$ and 9 cycles. Values are expressed as Mean \pm $\mathrm{SD}$ in triple experiments.

\section{Bioeffects of ultrasound on 293 cells}

PEI/DNA complexes: Similar transfection results were obtained in the use of PEI-DNA complexes on 293 cells compared to COS-7 cells. As in the experiment with COS cells, a significant increase in transfection efficiency at a $1 / 1$ ratio of PEI-DNA complexes was found (Figure $5 \mathrm{~A}, \mathrm{p}<0.05$ ) after the ultrasound treatment. Again, no additional cytotoxicity was observed from our test conditions with ultrasound (Figure 5B).

PDMAEMA/DNA complexes: In agreement with the findings of PDMAEMA-DNA complexes on COS cells, PDMAEMA-DNA complexes were optimally transfected at a ratio of $5 / 1$ followed by ratios of 3/1,2/1, 1/1, and 0.5/1 (Figure 6A). After ultrasound treatment, a $140 \%$ increase in transfection efficiency was observed for the $3 / 1$ and $5 / 1$ ratios (Figure 6A, p <0.05). When larger PDMAEMA-DNA complexes were used (ex. at $2 / 1$ ratio), ultrasound did not improve transfection efficiency (no statistical difference from control). Moreover, cell viability of 293 cells treated with PDMAEMA/DNA complexes was not influenced by ultrasound treatment (Figure 6B) which suggests that this is a safe and effective method to improve gene transfer.

\section{Discussion}

In this study, we used a transient, low intensity ultrasonic system to safely deliver genes in vitro. The resonant frequency around $2 \mathrm{MHz}$ (1.5 2.2 MHz in our use) was chosen because it is approved for clinical applications with advantages of good penetration through soft tissues and no influence on DNA integrity [23-25]. Also, the acoustic wave with a frequency around $2 \mathrm{MHz}$ helps in-depth transmission through the bottom of 96-well plates. Lower frequency (e.g. $500 \mathrm{kHz}$ ) would cause significant damage to DNA and a negative effect on cell viability [26]. Up to date, the exposure time and setting of ultrasound treatment (i.e. directions of irradiation, sequences in using ultrasound and cells to be transfected) were different. Our methodology has brought the use of ultrasound closer to the clinical setting. The ultrasound irradiation for only 10 seconds is rare and has only been used for transfection of naked DNA [27]. Meanwhile, very rare research is available on the subject of using ultrasound with polymer or liposome/DNA complexes [28,29].

Mechanisms of ultrasound to increase transfection efficiency have been shown in many studies. Acoustic cavitation effect either from air bubbles or added microbubbles is commonly accepted [30-32].

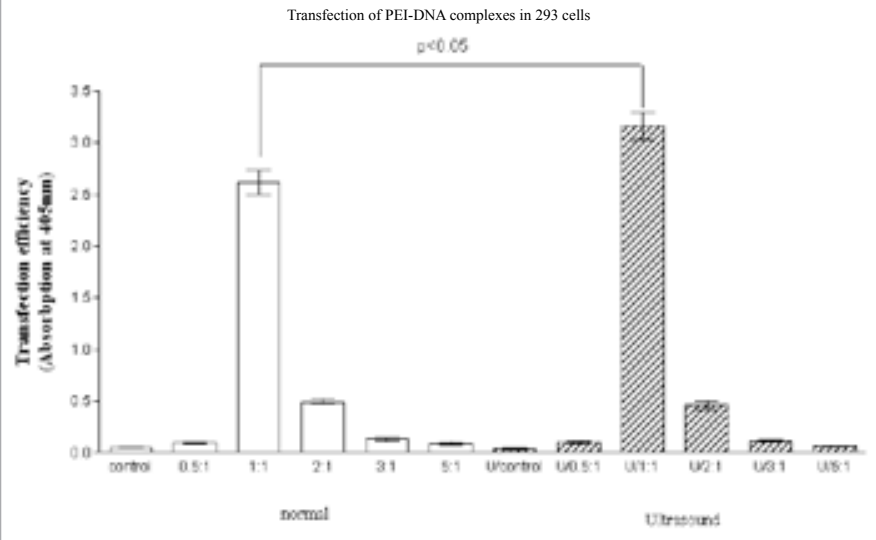

Figure 5A: Effects of the ultrasound treatment on transfection efficiency of PEI-DNA complexes at various ratios. Cells were treated with PEI-DNA complexes and ultrasound or without (normal group) a low energy ultrasound for $10 \mathrm{sec}$ and 9 cycles. Values are expressed as Mean \pm SD in triple experiments. Statistics are shown for cells treated with ultrasound $(p<0.05)$ compared to controls.

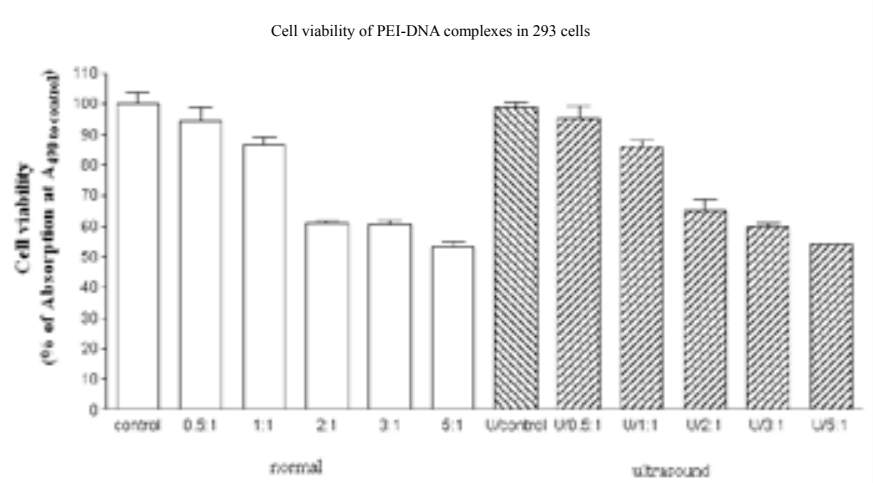

Figure 5B: Effects of ultrasound treatment on the cytotoxicity of PEI-DNA complexes at various ratios. Cells were treated with PEI-DNA complexes and employ ultrasound or without (normal) a low energy ultrasound for $10 \mathrm{sec}$ and 9 cycles. Values are expressed as Mean \pm SD. Triple experiments were performed. 
Citation: Shih MF, Wu CH, Cherng JY (2012) Bioeffects of Transient and Low-Intensity Ultrasound on Nanoparticles for a Safe and Efficient DNA Delivery. J Nanomedic Nanotechnol 6:276. doi:10.4172/2157-7439.1000276

Page 5 of 6

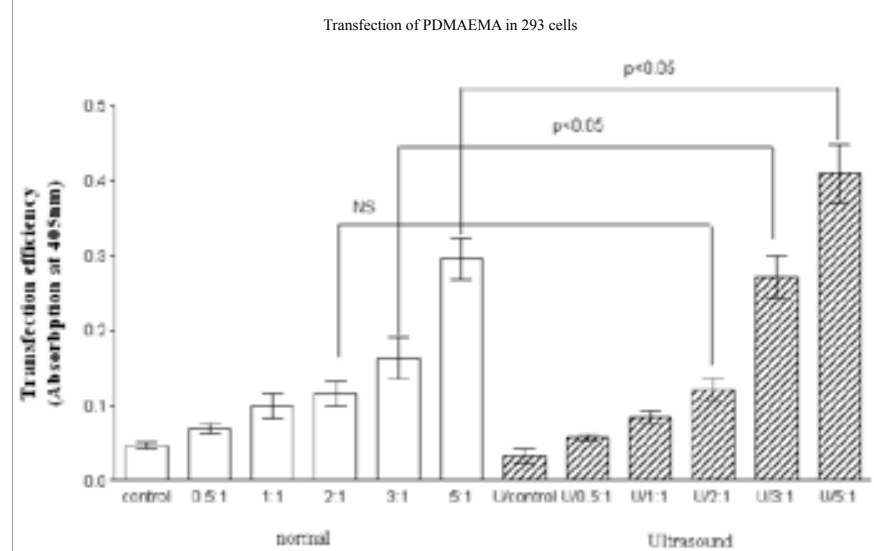

Figure 6A: Effects of the ultrasound treatment on transfection efficiency of PDMAEMA-DNA complexes at various ratios. Cells were treated with PDMAEMA-DNA complexes and ultrasound or without (normal) a low energy ultrasound for $10 \mathrm{sec}$ and 9 cycles. Values are expressed as Mean \pm SD in triple experiments. Statistics are shown for cells treated with ultrasound compared to untreated cells at ratio of $5 / 1(p<0.05), 3 / 1(p<0.05)$ and $2 / 1(N S)$

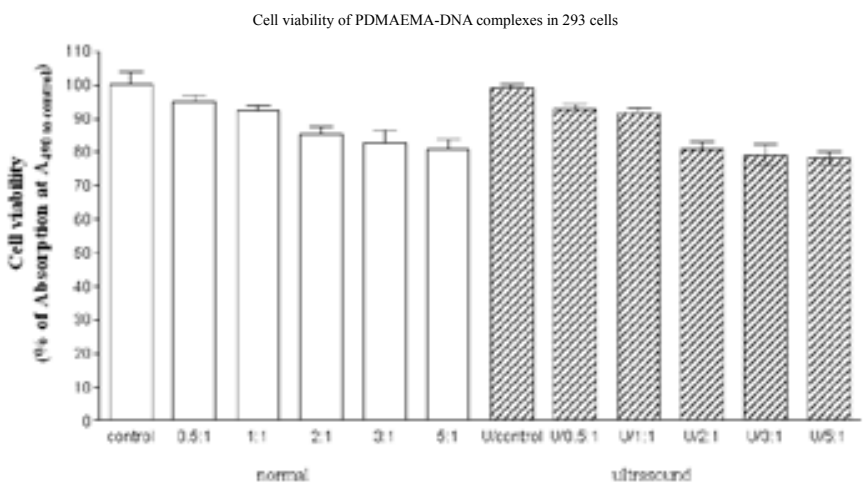

Figure 6B: Effects of the ultrasound treatment on cytotoxicity of PDMAEMA-DNA complexes at various ratios. Cells were treated with PDMAEMA-DNA complexes and ultrasound or without (normal group) a low energy ultrasound for $10 \mathrm{sec}$ and 9 cycles. Values are expressed as Mean \pm $\mathrm{SD}$ in triple experiments.

However, this effect also induce toxicity or apoptosis in cells due to disturbing the cell membranes [33-35] especially with high power of ultrasound (e.g. 130W) [36] or a combination of high power and low frequency (e.g. $20 \mathrm{kHz}$ ) [37] as we shown in Figure 1. Nevertheless, a cycle burst ultrasound treatment which we used only up to 10 seconds bypasses the problem of cytotoxicity without compromising the transfection efficiency. Besides the improvement in mechanical bioeffect from ultrasound, our methodology minimized the thermal bioeffect which might also contribute to cell toxicity [38].

Further key findings of our studies were: (1) the ratios for optimal transfection of polymer-DNA complexes are not affected before/ after ultrasound treatment (Figure 3A, 4A, 5A, 6A). This indicates that the ultrasound effect is evenly affecting complexes prepared at all polymer-DNA ratios; (2) the sizes of polymer-DNA complexes before/after ultrasound treatment were also not affected. Therefore, the reason of ultrasound in increasing transfection efficiency before/ after was not due to particle sizes nor cytotoxicity (Figure $3 \mathrm{~B}, 4 \mathrm{~B}$, $5 \mathrm{~B}, 6 \mathrm{~B})$; (3) for each polymer-DNA ratio, the extent of transfection efficiency enhancement by ultrasound is dependent to the particle size of polymer-DNA complexes, so smaller complex sizes lead to higher transfection efficiency (Figure 4A and Figure 6A).

\section{Conclusions}

A transient, low intensity ultrasound was found to be noncytotoxic and exhibited an ability to overcome the major limitations of polymer-DNA complexes such as low transfection efficiency. This new transfection method was shown to be a safe, simple and efficient approach with clinical applications for gene transfer.

\section{References}

1. Nomikou N, McHale AP (2010) Exploiting ultrasound-mediated effects in delivering targeted, site-specific cancer therapy. Cancer Lett 296: 133-143.

2. Frenkel V (2008) Ultrasound mediated delivery of drugs and genes to solid tumors. Adv Drug Deliv Rev 60: 1193-1208.

3. Park K, Hoffmeister B, Han DK, Hasty K (2007) Therapeutic ultrasound effects on interleukin- $1 \mathrm{~b}$ stimulated cartilage construct in vitro. Ultrasound Med Biol 33: 286-295.

4. Wu J, Pepe J, Rincon M (2006) Sonoporation, anti-cancer drug and antibody delivery using ultrasound. Ultrasonics 44: 21-25.

5. Chen YC, Jiang LP, Liu NX, Ding L, Liu XL (2011) Enhanced gene transduction into skeletal muscle of mice in vivo with pluronic block copolymers and ultrasound exposure. Cell Biochem Biophys 60: 267-273

6. Varkouhi AK. Lammers T, Schiffelers RM, van Steenbergen MJ, Hennink WE (2011) Gene silencing activity of siRNA polyplexes based on biodegradable polymers. Eur J Pharm Biopharm 77: 450-457.

7. Liu R, Gan L, Yang X, Xu H (2011) Chitosan as a condensing agent induces high gene transfection efficiency and low cytotoxicity of liposome. J Biosci Bioeng 111: 98-103.

8. Shiosaki S, Kuramoto M, Toita R, Mori T, Niidome T (2011) A hydrophilic polymer grafted with a histone tail peptide as an artificial gene regulator. Bioorg Med Chem 19: 4101-4105.

9. Kobulnik J, Kuliszewski MA, Stewart DJ, Lindner JR, Leong-Poi H (2009) Comparison of gene delivery techniques for therapeutic angiogenesis. J Am Coll Cardiol 54: 1735-1742.

10. Newman CM, Lawrie A, Brisken AF, Cumberland DC (2001) Ultrasound gene therapy: on the road drom concept to reality. Endocardiography 18: 339-347.

11. Phillips LC, Klibanov AL, Wamhoff BR, Hossack JA (2010) Targeted gene transfection from microbubbles into vascular smooth muscle cells using focused, ultrasound-mediated delivery. Ultrasound Med Biol 36: 1470-1480.

12. Chen Y J, Wang CJ, Yang KD, Chang P R, Huang HC (2003) Pertussis toxin-sensitive Gai protein and ERK-dependent pathways mediate ultrasound promotion of osteogenic transcription in human osteoblasts. FEBS Lett 554 154-158.

13. Suzuki R, Namai E, Oda Y, Nishiie N, Otake S (2010) Cancer gene therapy by IL-12 gene delivery using liposomal bubbles and tumoral ultrasound exposure. J Control Release 142: 245-250.

14. Delalande A, Bureau MF, Midoux P, Bouakaz A, Pichon C (2010) Ultrasoundassisted microbubbles gene transfer in tendons for gene therapy. Ultrasonics 50: 269-272

15. Suzuki R, Oda Y, Utoguchi N, Maruyama K (2011) Progress in the development of ultrasound-mediated gene delivery systems utilizing nano- and microbubbles J Control Release. 149: 36-41.

16. Carson AR, McTiernan CF, Lavery L, Hodnick A, Grata M (2011) Gene therapy of carcinoma using ultrasound-targeted microbubble destruction. Ultrasound Med Biol 37: 393-402.

17. Bekeredjian R, Grayburn PA, Shohet RV (2005) Use of ultrasound contrast agents for gene or drug delivery in cardiovascular medicine. J Am Coll Cardiol 45: 329-335.

18. Xiong $X$, Zhao F, Shi M, Yang $H$, Liu $Y$ (2011) Polymeric microbubbles for ultrasonic molecular imaging and targeted therapeutics. J Biomater Sci Polym Ed 22: 417-428.

19. Alter J, Sennoga CA, Lopes DM, Eckersley RJ, Wells DJ (2009) Microbubbles stability is a major determinant of the efficiency of ultrasound and microbubble mediated in vivo gene transfer. Ultrasound Med Biol 35: 976-984. 
Citation: Shih MF, Wu CH, Cherng JY (2012) Bioeffects of Transient and Low-Intensity Ultrasound on Nanoparticles for a Safe and Efficient DNA Delivery. J Nanomedic Nanotechnol 6:276. doi:10.4172/2157-7439.1000276

Page 6 of 6

20. McDannold N, Zhang Y, Vykhodtseva N (2011) Blood-brain barrier disruption and vascular damage induced by ultrasound bursts combined with microbubbles can be influenced by choice of anesthesia protocol. Ultrasound Med Biol 37: $1259-1270$.

21. Cherng JY, van de Wetering $P$, Talsma $H$, Crommelin DJA, Hennink WE (1996) Effect of size and serum proteins on transfection efficiency of poly ((2-dimethylamino)ethyl methacrylate)-plasmid nanoparticles. Pharm Res 13 1038-1042.

22. Hung WC, Shau MD, Kao HC, Shih MF, Cherng JY (2009) The synthesis of cationic polyurethanes to study the effect of amines and structures on their DNA transfection potential. J Control Release 133: 68-76.

23. Duvshani-Eshet M, Baruch L, Kesselman E, Shimoni E, Machluf M (2006) Therapeutic ultrasound-mediated DNA to cell and nucleus: bioeffects revealed by confocal and atomic force microscopy. Gene Ther 13: 163-172.

24. Chumakova OV, Liopo AV, Andreev VG, Cicenaite I, Evers BM, et al. (2008) Composition of PLGA and PEI/DNA nanoparticles improves ultrasoundmediated gene delivery in solid tumors in vivo. Cancer Lett 261: 215-225.

25. Feril Jr. LB, Ogawa R. Kobayashi, H, Kikuchi H, Kondo T (2005) Ultrasound enhances liposome-mediated gene transfection. Ultrason Sonochem 12: 489 493.

26. Deshpande MC, Prausnitz MR (2007) Synergistic effect of ultrasound and PE on DNA transfection in vitro. J Control Release 118: 126-135.

27. Chen YC, Liang HD, Zhang QP, Blomley MJK, Lu QL (2006) Pluronic block copolymers: novel functions in ultrasound-mediated gene transfer and against cell damage. Ultrasound Med Biol 32: 131-137.

28. Zhou QH, Miller DL, Carlisle RC, Seymour LW, Oupicky D (2005) Ultrasoundenhanced transfection activity of HPMA-stabilized DNA polyplexes with prolonged plasma circulation. J Control Release 106: 416-427.
29. Un K, Kawakami S, Suzuki R, Maruyama K, Yamashita F, et al. (2010) Development of an ultrasound-responsive and mannose-modified gene carrier for DNA vaccine therapy Biomaterials 31: 7813-7826.

30. Zhao YZ, Lu CT (2008) Hypothesis about the physical mechanism of gene transfer mediated by ultrasound contrast agent: chain cavitation effect. Biosci Hypotheses 1: 189-192.

31. Koch S, Pohl P, Cobet U, Rainov NG (2000) Ultrasound enhancement of liposome-mediated cell transfections is caused by cavitation effects. Ultrasound Med Biol 5: 897-903.

32. Reslan L, Mestas JL, Herveau S, Béra JC, Dumontet C (2010) Transfection of cells in suspension by ultrasound cavitation. J Control Release 142: 251-258.

33. Qiu Y, Luo Y, Zhang Y, Cui W, Zhang D (2010) The correlation between acoustic cavitation and sonoporation involved in ultrasound-mediated DNA transfection with polyethylenimine (PEI) in vitro. J Control Release 145: 40-48.

34. Furusawa Y, Zhao QL, Hassan MA, Tabuchi Y, Takasaki I (2010) Ultrasoundinduced apoptosis in the presence of Sonazoid and associated alterations in gene expression levels: A possible therapeutic application. Cancer Lett 288 107-115.

35. Otani K, Yamahara K, Ohnishi S, Obata H, Kitamura S (2009) Nonviral delivery of siRNA into mesenchymal stem cells by a combination of ultrasound and microbubbles. J Control Release 133: 146-153.

36. Fischer AJ, Stanke JJ, Omar G, Askwith CC, Burry RW (2006) Ultrasoundmediated gene transfer into neuronal cells. J Biotechnol 122: 393-411.

37. Kuo JHS, Jan MS, Sung KC (2003) Evaluation of the stability of polymer-based plasmid DNA delivery systems after ultrasound exposure. Int J Pharm 257 75-84

38. Wu J, Nyborg WL (2008) Ultrasound, cavitation bubbles and their interaction wit cells. Adv Drug Deliv Rev 60: 1103-1116.
This article was originally published in a special issue, Nanoengineered Systems: Single Cell Drug and Gene Delivery handled by Editor(s). Dr. Nanoengineered Systems: Single Cell Drug and Gene Delivery, Arizona State University, USA 